\title{
Health impacts of environmental contamination of micro- and nanoplastics: a review
}

\author{
Baorong Jiang ${ }^{1,2,3}$, Alexandra E Kauffman', Lei Li ${ }^{3}$, Wayne McFee ${ }^{4}$, Bo Cai ${ }^{2,5}$, John Weinstein ${ }^{6}$, Jamie R Lead ${ }^{1,2,7}$, \\ Saurabh Chatterjee ${ }^{1,2}$, Geoffrey I Scott ${ }^{1,2}$ and Shuo Xiao ${ }^{1,2,8^{*}}$ (D)
}

\begin{abstract}
Plastics are extensively used in our daily life. However, a significant amount of plastic waste is discharged to the environment directly or via improper reuse or recycling. Degradation of plastic waste generates micro- or nanosized plastic particles that are defined as micro- or nanoplastics (MNPs). Microplastics (MPs) are plastic particles with a diameter less than $5 \mathrm{~mm}$, while nanoplastics (NPs) range in diameter from 1 to 100 or $1000 \mathrm{~nm}$. In the current review, we first briefly summarized the environmental contamination of MNPs and then discussed their health impacts based on existing MNP research. Our review indicates that MNPs can be detected in both marine and terrestrial ecosystems worldwide and be ingested and accumulated by animals along the food chain. Evidence has suggested the harmful health impacts of MNPs on marine and freshwater animals. Recent studies found MPs in human stool samples, suggesting that humans are exposed to MPs through food and/or drinking water. However, the effect of MNPs on human health is scarcely researched. In addition to the MNPs themselves, these tiny plastic particles can release plastic additives and/or adsorb other environmental chemicals, many of which have been shown to exhibit endocrine disrupting and other toxic effects. In summary, we conclude that more studies are necessary to provide a comprehensive understanding of MNP pollution hazards and also provide a basis for the subsequent pollution management and control.
\end{abstract}

Keywords: Microplastics, Nanoplastics, Health impacts, Additives, Adsorbents

\section{Introduction}

Plastics are synthetic products that are typically made of organic polymers and other chemical additives, such as bisphenols, phthalates, and flame retardants, giving plastic products unique properties [1]. Plastics are used in a variety of commercial applications because of their low cost, ease of production, versatility, and hydrophobicity. The amount of plastics produced is increasing every

\footnotetext{
* Correspondence: sx106@pharmacy.rutgers.edu; sxiao@mailbox.sc.edu 'Department of Environmental Health Sciences, Arnold School of Public Health, University of South Carolina, Columbia, SC 29208, USA

${ }^{2} \mathrm{NIEHS}$ Center for Oceans and Human Health and Climate Change Interactions (OHHC2I), University of South Carolina, Columbia, SC 29208, USA Full list of author information is available at the end of the article
}

year; however, the strategies of reusing, recycling, and repurposing have not been implemented accordingly, particularly in some developing countries $[2,3]$. It is estimated that about 6.3 billion tons of plastic waste had been generated worldwide from 1950s to 2015 [4]. If this trend continues, that number will increase to 26 billion tons by $2050[4,5]$. However, only $21-26 \%$ of the plastic waste was appropriately recycled and incinerated. The rest is incinerated in open pits or discarded to the environment, leading to plastic pollution of the water, air, soil, etc. $[4,6,7]$.

After entering the environment, interactions between the plastic waste and environmental components can degrade large pieces of plastics to smaller plastic debris [8-

(c) The Author(s). 2020 Open Access This article is licensed under a Creative Commons Attribution 4.0 International License, which permits use, sharing, adaptation, distribution and reproduction in any medium or format, as long as you give appropriate credit to the original author(s) and the source, provide a link to the Creative Commons licence, and indicate if changes were made. The images or other third party material in this article are included in the article's Creative Commons licence, unless indicated otherwise in a credit line to the material. If material is not included in the article's Creative Commons licence and your intended use is not permitted by statutory regulation or exceeds the permitted use, you will need to obtain permission directly from the copyright holder. To view a copy of this licence, visit http://creativecommons.org/licenses/by/4.0/ The Creative Commons Public Domain Dedication waiver (http://creativecommons.org/publicdomain/zero/1.0/) applies to the data made available in this article, unless otherwise stated in a credit line to the data. 
10]. In addition, tiny plastic particles are commonly manufactured already and added to consumer products such as personal care products that are discarded after use, leading to another important direct source of plastic pollution in the environment [11-13]. According to the diameter of plastic fragments or particles, plastic particles can be divided into microplastics (MPs) and nanoplastics (NPs), with MPs being less than $5 \mathrm{~mm}$ in diameter and NPs being 1 to 100 or $1000 \mathrm{~nm}$ in diameter [14-19].

Thus far, micro- and nanoplastics (MNPs) have been detected worldwide in both marine and terrestrial ecosystems including oceans, rivers, air, drinking water, sediments, and food $[11,20,21]$. Previous studies have reported that the exposure of MNPs can cause reproductive toxicity in oysters [22], liver toxicity in zebrafish [23], and tissue bioaccumulation and potential organ toxicities in mice [24-27]. These results indicate that the pollution of MNPs is widespread, and the biological harm of MNPs to both humans and other living organisms cannot be ignored. However, the obtained experimental results are not conclusive; the conclusions given by different studies are somewhat conflicting; and the underlying mechanisms of discovered toxicities are still poorly understood. Moreover, recent studies have found MPs in human feces, suggesting that humans are exposed to MNPs through the food chain or food web [28, 29]. Nevertheless, the impact of MNPs on human health has been scarcely researched. Furthermore, in addition to the MNPs themselves, these tiny plastic particles can release plastic additives and/or adsorb other environmental chemicals, many of which have been shown to exhibit endocrine-disrupting and other toxic effects. However, how MNPs will impact the toxicities of these additives and adsorbents is still largely unknown. In this review, we therefore first reviewed the basic properties, sources, and abundance of MNPs in the environment and then discussed the health impacts of pristine MNPs as well as their associated adsorbents and additives.

\section{Type and use of plastics}

A main classification of plastics is based on the durability or non-durability of their shapes, or whether they are thermosets or thermoplastics. Thermosets include polyurethane, epoxy, and alkyd, and they are often used as insulators, adhesives, and plywood. The thermosetting process is primarily based on heat-induced crosslinking to form new and irreversible covalent bonds, which makes the thermosets stable and not easy to decompose [30]. On the contrary, thermoplastics have no newly formed chemical bonds and can be recycled and remolded, making them more widely used than thermosets in consumer goods [31-34]. There are four different kinds of thermoplastics: polyethylene (PE), polypropylene (PP), polystyrene (PS), and polyvinyl chloride (PVC). PE is used in a wide variety of inexpensive plastic products, including plastic bags and bottles. There are two commonly used subtypes of PE: (1) the highdensity polyethylene (HDPE), which is usually used in detergent bottles, milk cans, and molded plastic cases; and (2) the low-density polyethylene (LDPE) used in outdoor furniture, siding, floor tiles, shower curtains, and clamshell packaging. PP is primarily used to make bottle caps, drinking straws, yogurt containers, appliances, car bumpers, fishing lines, and plastic pressure pipe systems. PS is the primary chemical used to produce foam peanuts, food containers, plastic tableware, disposable cups, plates, cutlery, $\mathrm{CD}$ discs, and cassette boxes. PVC is the major component of plumbing pipes and guttering, shower curtains, window frames, and flooring. In addition to the typical plastic classifications listed above, microplastic fibers (MFs), which are made of polyester (PES) or PP, are one of the most common types of MPs found in the environment [35, 36]. MFs are commonly used in a variety of fibrous materials, such as clothing, agricultural, industrial, and household textiles, as well as some textile products, semi-finished or ancillary products used in other fields [37].

Generally, PE, PS, and PVC are three major types of MPs used in scientific research. PE and PS are the most popular plastic materials used in consumer products, and they have shorter service lives than other types of plastics. Additionally, PVC is primarily used for plastic wire insulation or the cable jacket of data cables. Once the life cycle of a cable ends, the metals in the cable will be recycled, but the plastic parts containing PVC are typically discarded into the environment because of the high cost of separation and limited recycling value. It has been reported that $82 \%$ of PVC waste is discarded in landfills, $15 \%$ is incinerated, and only $3 \%$ is recycled [38]. This relationship between the large output, short life cycle, and abundant environmental discharge of these plastics makes them the main focus of scientific research [24, 25, 39-41].

\section{MNPs in the environment}

MNPs, produced or made from a variety of types of plastics, are ubiquitous in the environment. Understanding where they come from and where they go can greatly help study their impacts on environment and human health. It is now generally accepted that MPs are plastic particles with a diameter less than $5 \mathrm{~mm}[15,16,42]$. NPs are generally considered to be nano-sized plastic particles, with diameters between 1 and either 100 or $1000 \mathrm{~nm}[1,14,17,18]$.

\section{Sources and formation of MNPs}

According to the formation mode, MNPs can be divided into primary MNPs and secondary MNPs [9]. Primary MNPs are processed plastic particles that are commonly 
added to personal care products [17, 43-46]. These PE microbeads are widely used as exfoliants in cosmetics, detergents, toothpastes, scrub facial cleansers, and drug carriers. Because the primary MNPs added to consumer products mainly serve as physical stimulus and carrier for cleaning; they are easy to be discharged into the environment after use [47]. In addition, a recent study also suggested that glitters that are commonly used in cosmetics, crafts, and textiles are another important source of plastic contamination caused by primary MNPs [48].

The second source of MNPs is plastic debris that degrades from the large pieces of plastics due to UV radiation, physical wear, and biodegradation in the environment [11-13, 17, 24, 49]. After plastics enter the environment, they are exposed to UV radiation that catalyzes the photo-oxidation of plastics, making them brittle. Upon further interactions with the wind, waves, and other abrasive interactions, the structural integrity of the plastics further weakens, and MNPs are formed and released from the plastic surface through delamination [9, 11-13, 16, 17, 24, 49-52]. These results indicate that both MPs and NPs can be produced in the degradation process of disposable plastic waste and accumulate over time $[18,53,54]$. Based on these facts, we summarized the pathway of environmental degradation of plastics as well as the production of MPs and NPs in Fig. 1.

\section{Occurrence of MNPs in the environment}

Both MPs and NPs have been found in the marine and terrestrial ecosystems, including oceans, rivers, air, drinking waters, sediments, and foods, worldwide [11, $20,21,55]$. For example, MPs can be detected in most of the oceans, and they can also be absorbed and bioaccumulated by marine animals. Thus, the study of the health impacts of MPs on animals is an important research direction $[55,56]$. In addition, MPs has been found to be present in the soil as well as in earthworms that live on the surface and deep layers of the soil [5760]. In Table 1, we summarized the literatures focusing on the current environmental pollution of MNPs since 2016, including detection regions, sample sources, abundance, size, and qualitative and quantitative methods. Studies published before 2016 are summarized in another review manuscript [21].

There are some common detection methods for MNPs, including Raman spectroscopy, micro-Fourier-

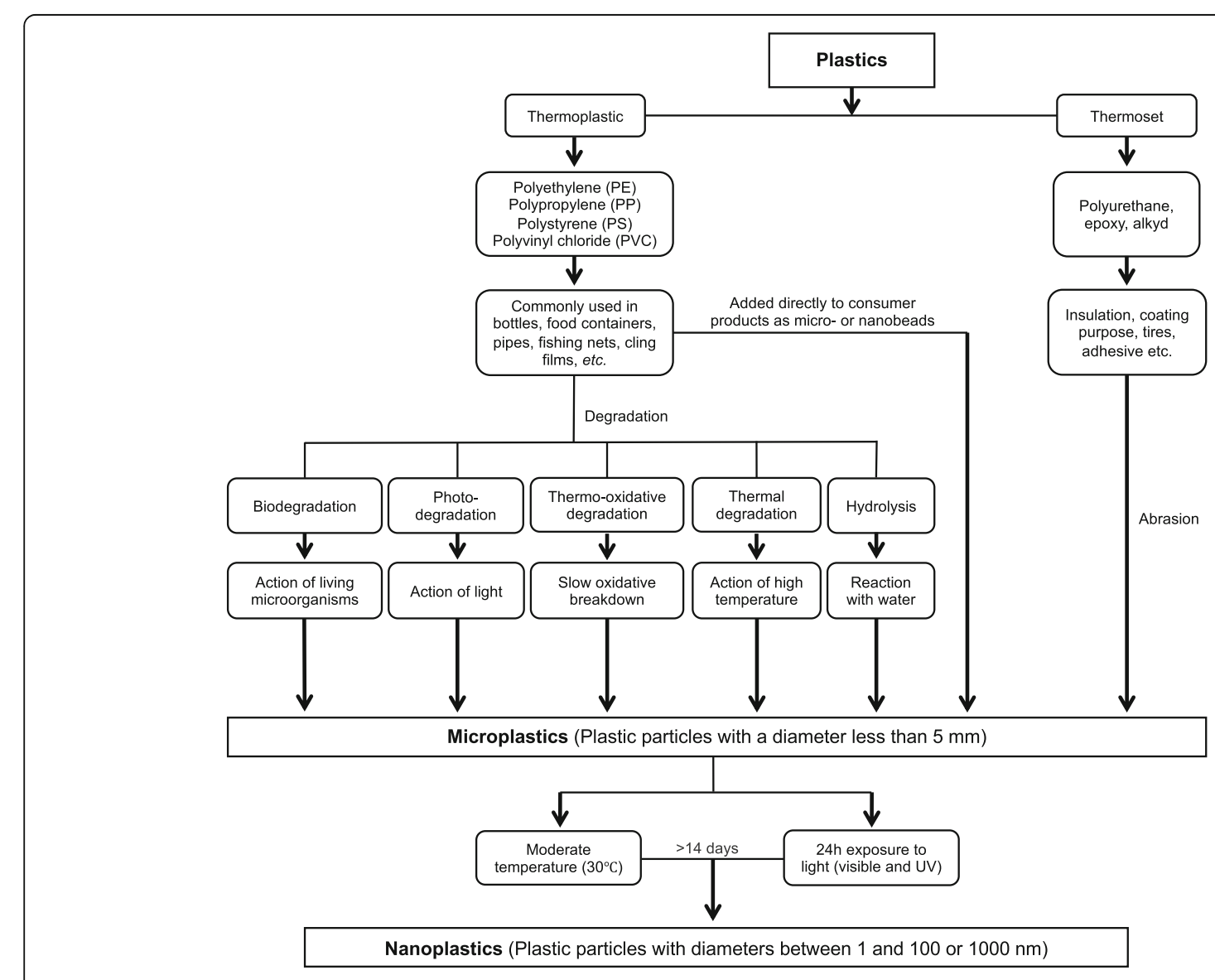

Fig. 1 A summary of possible environmental degradation pathway of plastics. This schematic is drawn based on [11, 18] 
Table 1 Summary of published studies providing data on abundance, size range, and qualitative and quantitative methods of micro- and nanoplastics (MNPs) from 2016 to 2020

\begin{tabular}{lllll}
\hline Region & Sample & Abundance & Size range & Ref \\
\hline Lake Winnipeg, Canada & Water & $\begin{array}{l}193,420 \pm 115,567 \\
\text { particles } / \mathrm{km}^{2}\end{array}$ & $<5 \mathrm{~mm}$ & {$[61]$}
\end{tabular}

Qualitative method: dissecting microscope, scanning electron microscope (SEM), energy dispersive X-ray spectroscopy (EDX)

Quantitative method: The package "ggmap" and "ggplot2"

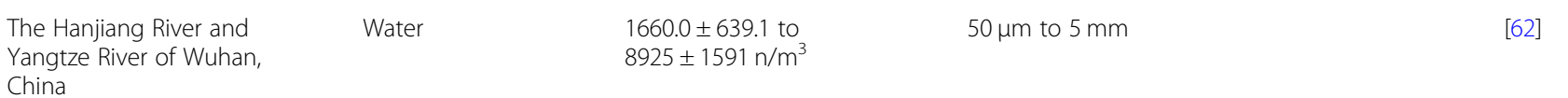

Qualitative method: stereoscopic microscope, SEM, Fourier-transform infrared spectroscopy (FTIR)

Quantitative method: microscope counting
Drinking bottled waters,
Water
$193 \pm 162$ particles/l
1 to $500 \mu \mathrm{m}$

Germany

Qualitative method: micro-Raman spectroscopy

Quantitative method: micro-Raman spectroscopy with binary computer

$\begin{array}{ll}\text { Drinking water treatment plants, Water } & 1473 \pm 34 \text { to } 3605 \pm 497 \quad 1 \text { to } 10 \mu \mathrm{m} \\ \text { The Czech Republic } & \text { particles/l in raw water, } \\ & 338 \pm 76 \text { to } 628 \pm 28 \\ & \text { particles/l in treated water }\end{array}$

Qualitative method: FTIR spectrometer Nicolet 6700, Raman spectroscopy, SEM-EDX

Quantitative method: VEGA high-resolution SEM

\begin{tabular}{|c|c|c|c|c|}
\hline $\begin{array}{l}\text { All steps of drinking water } \\
\text { purification, transportation, } \\
\text { and supply in drinking water } \\
\text { treatment plants (DWTP) }\end{array}$ & Water & $\begin{array}{l}0 \text { to } 7 \text { microplastics } / \mathrm{m}^{-3} \\
\text { (raw water), } 0.7 \\
\text { microplastics } / \mathrm{m}^{-3} \\
\text { (drinking water) }\end{array}$ & 50 to $150 \mu \mathrm{m}$ & [65] \\
\hline \multicolumn{5}{|c|}{ Qualitative method: micro-FTIR } \\
\hline \multicolumn{5}{|c|}{ Quantitative method: micro-FTIR } \\
\hline Tyre wear and tear simulator & $\begin{array}{l}\text { Tyre wear and tear } \\
\text { particles }\end{array}$ & $0.81 \mathrm{~kg} /$ year per capita & $10 \mathrm{~nm}$ to $100 \mu \mathrm{m}$ & $\begin{array}{l}{[53,} \\
54]\end{array}$ \\
\hline
\end{tabular}

Qualitative method: particle size analyzer, SEM-EDX, TLM, transmission electron microscopy (TEM)

Quantitative method: the tyre number weight loss method, the emission factor per vehicle-km approach

$\begin{array}{lll}\begin{array}{l}\text { The Changjiang Estuary, China Sediment } \\ \text { Qualitative method: micro-FTIR }\end{array} & \begin{array}{l}121 \pm 9 \text { items } / \mathrm{kg} \text { of } \\ \text { dry weight }\end{array} & 1174.5 \pm 41.8 \mu \mathrm{m} \\ \begin{array}{l}\text { Quantitative method: micro-FTIR } \\ \text { Rivers and tidal flat in Shanghai } \quad \text { Sediment }\end{array} & \begin{array}{l}802 \pm 594 \text { items } / \mathrm{kg} \\ \text { of dry weight }\end{array} & 100 \mu \mathrm{m} \text { to } 5 \mathrm{~mm} \\ \begin{array}{l}\text { Qurban districts, China } \\ \text { Qualitative method: microscopic observations, micro-FTIR }\end{array} & \text { [67] } \\ \begin{array}{l}\text { Quantitative method: weighing method } \\ \text { The coastline of Tamil Nadu, Sediment }\end{array} & 46.6 \pm 37.2 / \mathrm{m}^{2} & 0.3 \text { to } 4.75 \mathrm{~mm}\end{array}$

The coastline of Tamil Nadu, Sediment

Qualitative method: NIKON stereoscopic microscope fitted with a digital camera, Perkin Elmer, attenuated total reflectance (ATR) FTIR (ATR-FTIR)

Quantitative method: FTIR

Water $\quad 6.6 \pm 1.3$ particles/l $\quad>63 \mu \mathrm{m}$

Qualitative method: ATR-FTIR, dissecting microscope

Quantitative method: FTIR

Winyah Bay, USA. Water $\quad$ Wascope

$30.8 \pm 12.1$ particles $/ \mathrm{l} \quad>63 \mu \mathrm{m}$

Qualitative method: ATR-FTIR, dissecting microscope

Quantitative method: FTIR

Spanish table salt

Salt

50-280 MPs/kg salt

$30 \mu \mathrm{m}$ to $3.5 \mathrm{~mm}$ 
Table 1 Summary of published studies providing data on abundance, size range, and qualitative and quantitative methods of micro- and nanoplastics (MNPs) from 2016 to 2020 (Continued)

\begin{tabular}{|c|c|c|c|c|}
\hline Region & Sample & Abundance & Size range & Ref \\
\hline \multicolumn{5}{|c|}{ Qualitative method: stereo microscopy, FTIR } \\
\hline \multicolumn{5}{|l|}{ Quantitative method: FTIR } \\
\hline Table salts for sale, China & $\begin{array}{l}\text { Sea salts, lake salts, } \\
\text { and rock/well salts }\end{array}$ & $\begin{array}{l}\text { 550-681 particles/kg (sea salts), } \\
\text { 43-364 particles/kg (lake salts), } \\
\text { and } 7-204 \text { particles/kg } \\
\text { (rock/well salts) }\end{array}$ & $<200 \mu \mathrm{m}$ & [71] \\
\hline \multicolumn{5}{|c|}{ Qualitative method: Carl Zeiss Discovery V8 stereomicroscope, micro-FTIR } \\
\hline \multicolumn{5}{|c|}{ Quantitative Method: microscopic observation, micro-FTIR } \\
\hline $\begin{array}{l}\text { The Fram Strait, the Barents Sea } \\
\text { slope and the Central Arctic }\end{array}$ & Sea ice & $11.7 \pm 7.6 \mathrm{~N} / \mathrm{m}^{3}$ & $<50 \mu \mathrm{m}$ & [72] \\
\hline \multicolumn{5}{|c|}{ Qualitative method: a Hyperion 3000 microscope (Bruker Optics) attached to a Tensor 27 (Bruker Optics) spectrometer, imaging FTIR } \\
\hline \multicolumn{5}{|c|}{ Quantitative method: focal plane array (FPA) FTIR microscopy and image analysis } \\
\hline $\begin{array}{l}\text { Southeastern National Park } \\
\text { Service (NPS) units, USA }\end{array}$ & Sand & 43 to 443 pieces $/ \mathrm{kg}$ sand & $\begin{array}{l}\sim 20 \mu \mathrm{m} \text { in width and varied highly }(0.1 \text { to } 11 \mathrm{~cm}) \\
\text { in length }\end{array}$ & [73] \\
\hline \multicolumn{5}{|l|}{ Qualitative method: FTIR } \\
\hline \multicolumn{5}{|c|}{ Quantitative method: microplastic quantification (AM3011 digital microscope) } \\
\hline Switzerland & Soil & Not mentioned & $1-5 \mathrm{~mm}$ & {$[74]$} \\
\hline \multicolumn{5}{|l|}{ Qualitative method: ATR-FTIR } \\
\hline \multicolumn{5}{|c|}{$\begin{array}{l}\text { Quantitative method: precisely measuring the size of the single particles and calculating their weight using an empirical relationship between } \\
\text { particle size and weight }\end{array}$} \\
\hline $\begin{array}{l}\text { The central district of } \\
\text { Tehran, Iran }\end{array}$ & Deposited urban dust & $\begin{array}{l}\text { Adults: } 1063 \text { particles/ } \\
\text { year; Children: } 3223 \\
\text { particles/year }\end{array}$ & 250 to $500 \mu \mathrm{m}$ & {$[75]$} \\
\hline \multicolumn{5}{|c|}{ Qualitative method: SEM, EDX detector } \\
\hline \multicolumn{5}{|c|}{ Quantitative method: binocular microscope } \\
\hline $\begin{array}{l}\text { The North Atlantic subtropical } \\
\text { gyre }\end{array}$ & Seawater & $\begin{array}{l}\text { Several populations } \\
(13-501 \text { plastic debris } \\
\left.\text { per } \mathrm{m}^{3}\right)\end{array}$ & 1 to $1000 \mathrm{~nm}$ & [18] \\
\hline \multicolumn{5}{|c|}{$\begin{array}{l}\text { Qualitative method: dynamic light scattering (DLS) experiments, FTIR, pyrolysis coupled with gas chromatography-mass spectrometry, } \\
\text { microscope imaging }\end{array}$} \\
\hline \multicolumn{5}{|c|}{ Quantitative method: principal component analysis (PCA) } \\
\hline
\end{tabular}

transform infrared spectroscopy (Micro-FTIR), scanning electron microscopy (SEM), transmission electron microscopy (TEM), and energy dispersive X-ray (EDX) [53, $54,61,62,64-73,75]$. Studies focused on the contamination of NPs have just begun, with the first discovery of NPs in the North Atlantic subtropical circulation [18]. The lack of research on NPs is mainly due to the inability of analytical techniques applied to MPs, such as FTIR and Raman spectroscopy, to be used for nano-sized particles. Furthermore, other methods established for characterizing NPs, such as TEM, are unable to clearly distinguish between plastics and other materials such as natural organic matter. Recently, the scanning transmission X-ray microscope (STXM) was used to analyze NPs in soils at a resolution of about $30 \mathrm{~nm}$. However, this experiment only introduced the usability of this method, and the specific results were not given [74]. Additionally, other studies have shown that MNPs can be detected by optical measurement, which provides a basis for later detection methods $[76,77]$. Building on the studies investigating the distribution of MPs before 2015 [21], recent studies have increasingly focused on the pathways that allow direct exposure of MPs to humans, such as drinking water and table salt $[33,63,64,70,71]$. Taken together, although MNPs have been detected in the biosphere of the sea, land, air ecosystems, and food (chains), at present, there is no unified qualitative and quantitative method to identify their presence or quantify them. Therefore, it is challenging to analyze the real abundance of MNPs accurately in the environment.

\section{Health impacts of MNPs}

In response to the studies suggesting that MPs are ubiquitously present in various environment media, their health impacts on both humans and other organisms have become one of the research foci. Moreover, the 
trophic transfer of plastic particles may be a common phenomenon that occurs at the same time, making the health impact of MNPs extensive and complex [49]. A recent review summarized the presence of MNPs in animals and foods and elucidated the widespread biological exposure of MNPs [78], suggesting that understanding the health impacts of MNPs is an urgent and unmet need. Here, the health impacts of MNPs themselves, the adsorbents, and the plastic additives are reviewed and discussed.

\section{Health impacts of pristine MNPs Health impacts of MNPs on marine animals}

Since oceans can serve as the ultimate repository for plastic waste, numerous studies focusing on the health impacts of MNPs used non-mammalian marine animals as research models $[55,79]$. Furthermore, some of these organisms, such as most of the bivalves, are also used because they are an important food source for humans, representing one pathway by which human may be exposed directly to plastic particles.

Bivalves are a group of animals that lack some of the common molluscan organs, such as the radula and odontophore, so they cannot chew when they eat. All their ingested food goes directly into the digestive system and can be used in MNPs research [80-85]. Most bivalves are filter feeders, including oysters, clams, shellfish, mussels, etc. As a result, they eat plastic particles small enough to accumulate in their bodies and cause harmful health effects. Studies have found that plastic particles larger than $4 \mu \mathrm{m}$ can remain in the body of the blue mussel, and particles smaller than $10 \mu \mathrm{m}$ can accumulate in the gut and be absorbed into their circulatory system [21, 86]. In addition, another study found that when blue mussel (Mytilus edulis) larvae were exposed with the same mass of plastic particles, the intake of $2 \mu \mathrm{m}$ particles was more than the smaller particles with diameter at $100 \mathrm{~nm}$ [87]. The differential intakes of different-sized plastic particles may be due to the fact that the $2-\mu \mathrm{m}$ particles were mistakenly ingested as food $(1-9 \mu \mathrm{m})$, while the $100-\mathrm{nm}$ particles float in the water and enter the digestive tract passively with the water. Results from the same study showed that although the growth of blue mussel larvae was not affected, abnormal development increased, and malformation appeared in all treatment groups $(0.42 \mathrm{~g} / \mathrm{L}, 28.2 \mathrm{~g} / \mathrm{L}$ and $282 \mathrm{~g} / \mathrm{L})$ of both sizes of plastic particles [87]. Another study found that oyster larvae can generally ingest plastic particles of $160-7.3 \mu \mathrm{m}$. Additionally, when oyster Crassostrea gigas larvae (3-24 days post fertilization, d.p.f.) were exposed to 1 - and $10-\mu \mathrm{m}$ PS particles for 8 days at the concentrations of $0.11 \times 10^{-3} \mu \mathrm{g} / \mathrm{ml}$ and $0.18 \mathrm{~g} / \mathrm{ml}$, respectively, there was no measurable adverse effect on the growth, development, or feeding capacity [88]. Another study reported that adult oysters ate PS microspheres and preferred 6 to $2-\mu \mathrm{m}$ particles at the exposure concentration of $0.023 \mathrm{mg} / \mathrm{l}$ [22]. It was postulated that the adult oysters preferred 6- to $2-\mu \mathrm{m}$ plastic particles because $6-\mu \mathrm{m}$ particles were more similar in size and shape to their diet [22]. In the same study, MPs was found to significantly reduce the number of follicles and sperm motility in oysters as well as the production and development of offspring larvae after a 2-month maternal exposure experiment [22]. Similarly, another study also reported that exposure to $50 \mathrm{~nm}$ NPs can lead to a significant decrease of oyster fertilization rates and embryo-larval development, including many deformities, which results in the complete stagnation of development [89].

MPs have been found to present in the soft tissues of two common bivalves that humans consume: Mytilus edulis and Crassostrea gigas [39, 84, 90]. Based on the abundance of MPs in the bodies of these two commercial bivalves, European consumers of shellfish are estimated to intake 11,000 kinds of MPs in their diet each year, indicating that the MPs accumulated in bivalves could be an important exposure route for people who consume seafood [84]. Among different sources of clams (Venerupis philippinarum), studies found that there was no significant difference for the intake and accumulation of MNPs between wild and farmed clams, with the concentration of detected plastics ranging from 0.07 to 5.47 particles/g [91]. Moreover, researchers found that the characteristics of MPs in clams are similar to those in sediments, suggesting that clams can be used as a biological indicator of microplastic pollution in sediments [92].

There are also studies looking at the possible biological changes caused by plastic particles in other marine animals. For instance, lugworms (deposit feeders) are large marine worms of the phylum Annelida. In the natural ecological environment of the coastline of northern Europe, there were $1.2 \pm 2.8$ particles/g in the lugworms (Arenicola marina) [39]. However, results also showed that these accumulated plastic particles did not have significant effects on the organisms, nor did they enhance or weaken the bioaccumulation of other chemicals [93]. The results from another study using Dunaliella salina indicated that $200 \mu \mathrm{m}$ MPs, which are larger than a cell, promoted $D$. salina's growth and photosynthesis at the concentrations of $200,250,300$, and $350 \mathrm{mg} / \mathrm{l}$ and that the adverse effects increased as the diameter of MPs decreased. These results suggested that the size of MPs is closely related to the corresponding biological effects, and that NPs may cause more serious biological toxicity than MPs [94]. Regarding marine invertebrates, studies reported that larval and juvenile Crepidula onyx grew slowly after exposure to relatively high concentrations $\left(1.4 \times 10^{5}\right.$ particles $\left./ \mathrm{ml}\right)$ of micro-PS, suggesting that MP exposure may cause abnormal energy consumption [95]. 
The results described above indicate that MNPs of different sizes can be differentially absorbed and accumulated by marine organisms, and the ingested plastic particles have various health impacts on different marine species. Most marine filter feeders prefer to ingest MNPs less than $10 \mu \mathrm{m}$, and NPs are smaller than MPs and more likely to be ingested, leading to higher concentrations in the body and greater toxicity in circulation. In addition to the size-dependent effects, there is also dosedependent effect of MNPs. The toxicity of any substance is determined by its concentration and diameter and other physical parameters. Therefore, the size of the MNPs and the high and low concentrations will cause inconsistency in the toxic effects caused by MNPs. More sophisticated and targeted evaluations are necessary to determine the health impacts of MNPs on marine animals.

\section{Health impacts of MNPs on freshwater organisms}

The impact of MNPs on organisms found in freshwater habitats has also attracted extensive attention. Studies have shown that different concentrations of MNPs in the terrestrial aquatic ecosystems have various degrees of influences on the growth, development, behavior, reproduction, and mortality of aquatic animals (represented by Daphnia and zebrafish) [15].

Daphnia magna (D. magna) is a small planktonic crustacean with adult length at $1.5-5.0 \mathrm{~mm}$. They are widely used in aquaculture and aquaria as fish food and have been used as one of the biological research subjects since the 18th century. More importantly, D. magna is used in the OECD Guidelines for the Testing of Chemicals in ecotoxicology. In recent years, studies about the effects of plastic fragments on aquatic organisms using D. magna have focused on the bioaccumulation of plastic particles in their intestinal tissues, survival rate after exposure, and possible reproductive toxicity. In one study with exposure to four types of environmentally relevant MPs at the concentration of $100 \mathrm{mg} / \mathrm{l}$ for $48 \mathrm{~h}$, MPs were found in the gut of D. magna, but no acute effects were observed [96]. Additionally, after a short-term exposure of $12.5-400 \mathrm{mg} / \mathrm{l}$ with diameters of $1 \mu \mathrm{m}$ and $100 \mu \mathrm{m}$ PE MPs for $96 \mathrm{~h}$, Rehse and colleagues found that the effect of $1-\mu \mathrm{m}$ plastic particles on D. magna immobilization changed in a time- and dose-dependent manner. However, the $100-\mu \mathrm{m}$-sized plastic particles could not be ingested, and there was also no significant harmful effect for this size of plastic particles [97]. Another study used $100 \mathrm{~nm}$ and $2 \mu \mathrm{m}$ fluorescent PS MPs to investigate the effect of MPs on the feeding and reproduction rate of $D$. magna. This study was divided into two parts. First, the animals were exposed to $1 \mathrm{mg} / \mathrm{l}$ MPs for $24 \mathrm{~h}$ and were then purified for $24 \mathrm{~h}$ to assess the intake of MPs in the animals. The second part was a 21-day exposure of $0.1 \mathrm{mg} / \mathrm{l}, 0.5 \mathrm{mg} / \mathrm{l}$, and $1 \mathrm{mg} / \mathrm{l} \mathrm{MP}$, respectively, to determine the toxic effect of MPs on the reproduction of $D$. magna. Their results showed that both of sizes of MPs were easy to ingest, and the intake of 2- $\mu \mathrm{m}$ particles was five times higher than the 100-nm particles. After 21 days of exposure to $0.1 \mathrm{mg} / \mathrm{l}, 0.5 \mathrm{mg} / \mathrm{l}$, and $1 \mathrm{mg} / \mathrm{l} \mathrm{MPs}$, there was no observed adverse effect on reproduction. However, the exposure of 100-nm MPs resulted in a reduction in the excretion rate and feeding rate of $D$. magna, indicating that plastic particles in the nanoscale were more harmful to $D$. magna. than those in the microscale [98]. This may be because NPs are small in diameter and are more likely to remain in the digestive tract, where physical accumulation leads to a false sense of fullness, prompting organisms to eat less. Other studies have reported no increase in adult $D$. magna mortality after MP exposure, no change in morphology (length, width, and tailbone length), and no harmful effect on reproductive parameters. Taken together, these results suggest that the ingested MNPs can pass through the gut of D. magna; however, whether the absorbed MNPs will result in adverse health impacts on D. magna requires further investigation [96-100].

Zebrafish (Danio rerio) is a type of ornamental freshwater fish and has been widely used as a vertebrate model in toxicological research. The absorption and accumulation patterns of zebrafish has been examined using a 7-day exposure to $5 \mu \mathrm{m}$ and $20 \mu \mathrm{m}$ of PS MPs at the concentrations of $20 \mathrm{mg} / \mathrm{l}$. In the same study, the liver toxicity was also investigated using a 3-day exposure of 70-nm and 5- $\mu \mathrm{m}$ PS MPs at the concentrations of 20,200 , and $2000 \mathrm{mg} / \mathrm{l}$. The results showed that $5-\mu \mathrm{m}$ PS MPs can accumulate in the gills, liver, and gut, but 20- $\mu \mathrm{m}$ PS MPs could not accumulate in the gill tissue. The results of organ toxicity assessment indicated that both $70-\mathrm{nm}$ and 5- $\mu \mathrm{m}$ PS MPs can induce inflammation and lipid accumulation in the liver. Meanwhile, changes of oxidative stress and lipid energy metabolism were noted by analyzing the increase or decrease of some enzyme activities [23]. Another study has shown that MPs do not cause or rarely cause death in zebrafish (Danio rerio) after a 10-day exposure to $0.001-10.0 \mathrm{mg} / \mathrm{l} \mathrm{MPs}$. However, intestinal damages, including cracking of villi and splitting of enterocytes, were noted after exposure to all four common MPs, including polyamides (PA), PE, PP, and PVC [101]. The exposure of NPs has been found to result in developmental toxicity in zebrafish. When zebrafish embryos were exposed to $0.1,1$, or $10 \mathrm{ppm}$ of PS NPs $24 \mathrm{~h}$ post-fertilization (hpf) with an average diameter of $51 \mathrm{~nm}$, the NPs were found to accumulate in the yolk sacs and migrate to the gastrointestinal tract, gallbladder, liver, pancreas, heart, and brain at 48-120 hpf. The accumulation of PS NPs decreased during the purification period of all organs (120-168 hpf), but the 
clearance rate of the pancreas and gastrointestinal tract was slower than other organs. Notably, exposure to PS NPs did not result in significant mortality, malformation, or mitochondrial bioenergy changes, but reduced the heart rate of zebrafish embryos. In conclusion, these data suggest that NPs can penetrate the choroid membranes of developing zebrafish, accumulate in embryonic tissues, and influence physiology and behavior, leading to inter- or transgenerational toxicity $[102,103]$.

In addition to using the commercially uniform MNPs, the isolated MNPs from environmental samples is a more realistic and representative approach to perform the exposure experiments. A recent study found that a 21-day exposure of MFs increased oviposition and secondary patellar aneurysms in adult Japanese medaka (Oryzias latipes) at the concentration of 10,000 particles/l [35]. This study provides some insight that MNPs obtained from environmental samples can be directly used in toxicological assessments. Compared with the commercially produced plastic microspheres, the natural MNPs with environmental separation has more research value and exploration significance.

\section{Effects of MNPs on mammalian species}

Recently, researchers have begun to use mammalian animal models to predict the potentially harmful impact of MNPs on human health. It has been found that mice exposed to PS MPs with diameters at 5 and $20 \mu \mathrm{m}$ for 28 days showed the presence of MPs in the liver, kidney, and gut [24]. Moreover, the results related to energy, lipid metabolism, etc. suggested the possible harmful effects after exposure to MPs. For example, the levels of $\mathrm{T}-\mathrm{CHO}$ and $\mathrm{TG}$ were significantly reduced in the MP-treated group, and lipid droplets were detected in the liver, suggesting that MPs can cause lipid metabolism disorders and liver inflammation in mice. Another two studies have shown that mice exposed to PS MPs had decreased intestinal mucus and significant changes in the richness and diversity of intestinal biota [26, 27]. Regarding NPs, Rafiee et al. analyzed the effect of long-term exposure of PS NPs on neural behavior in rats. Specifically, adult male Wistar rats were exposed to 1-, 3-, 6-, and 10-mg PS NPs/kg of body weight/day. The particles had an average diameter of $38.92 \mathrm{~nm}$ and were exposed orally for 5 weeks. Results indicated that no significant behavioral effects were noted in all neurobehavioral tests. However, some subtle toxic effects, such as decreased locomotor activity, were observed, which provides insight for future studies [104].
Based on the results obtained from mammalian animal models, it is reasonable to assume that plastic particles can possibly accumulate and affect human health. According to the results in Table 1, the average abundance of MNPs in drinking water is 193 particles/l, which is much lower than the concentration used in the cited studies above. However, based on the fact that people drink $1200-1600 \mathrm{ml}$ water per day, it may be important to consider the long-term exposure to MNPs. Additionally, MNPs have also been detected in table salt, honey, and sugar, indicating other sources of MNP exposure to humans [21]. However, there are no accurate data to determine the daily exposure and intake of MNPs. It is also not conclusive that whether the MNPs absorbed by the human body enter the internal circulation through gastrointestinal tract and ultimately cause organ damage. Therefore, more exposure and toxicity assessments using human relevant experimental models are necessary.

\section{Effects of adsorbents of MNPs}

Current studies suggest that hazardous chemicals can be adsorbed onto MNPs, and these adsorbed pollutants on MNPs could be many orders of magnitude higher in concentration than those detected in the surrounding environment [40]. Moreover, new studies support the possibility that the adsorbed chemicals exhibit more toxicity than pure chemical alone [40]. Here, we used hydrophobic organic chemicals (HOCs) and heavy metals as examples to review the toxicity of the chemicals involved, their ability to adsorb onto MNPs, and their toxicity when together. Since the current evidence on NPs is limited, we primarily focused on the adsorption of environmental chemicals on MPs.

HOCs exist in many varieties in the environment, and many of them are known to be endocrine-disrupting chemicals (EDCs), such as the PCBs (polychlorinated biphenyls), PFCs (perfluorinated chemicals), BPA (bisphenol-A), and phthalates [105]. HOCs have been shown to adsorb onto MPs. For example, one study measured the partition coefficients between MPs and seawater for various types of HOCs [106]. These results revealed a high sorption capacity of MPs over the aqueous phase, suggesting that MPs can enhance the environmental exposure as well as the corresponding toxicities when coexisting with HOCs. Similar to what we have discussed above, these results are speculated to be a result of the addition of MPs, which, when ingested, facilitated the transfer of PCBs to the organisms.

In terms of heavy metals, MPs can sorb metals from both aquatic and sedimentary environments, allowing 
for an accumulation of these metals [107]. Additionally, a 12-month study from Rochman et al. demonstrated an increased pattern of several types of heavy metals over time, including cadmium, nickel, zinc, and lead. This suggests that the longer MPs stay at the sea, the more metals they can accumulate. Thus, a mixture of metals, including those listed as priority pollutants by the US EPA, can be found on plastic debris [108]. Heavy metals are a potential hazard to both wildlife animals and humans. For example, mercury has been observed to bioaccumulate alongside MPs in Dicentrarchus labrax, the sea bass, and the analysis of mercury detected in the brain and muscle tissues found significant interactions between mercury and MPs [109].

These studies raise concern for the possibility that the body can uptake not only the MPs, but also the adsorbed toxic chemicals that MPs carry. There is also the possibility that a combination of MPs and their adsorbed chemicals can be more toxic than either counterpart on its own. A study examined the exposure to both MPs and organophosphorus flame retardants (OPFRs), which are a type of HOC. The results demonstrated that the co-exposure of these particles induced greater oxidative stress, neurotoxicity, and metabolic disruption in mice than either the MPs or OPFR alone [40]. This could be simply due to an increase in uptake of the toxic chemicals in the presence of MPs. Another possible reason may be that the sorption and desorption equilibrium of the HOC and MPs could slow down the metabolism in mice, causing higher toxicity [40] or, quite simply, it could be explained by the separate toxicity of the MPs and the HOCs, which were both still ingested. These results make MPs even more complex to understand because examining pure plastics in the lab and their impact does not address how plastics adsorb chemicals. Recent studies have also found that PS NPs and natural acidic organic polymers (NAOP) such as fulvic acid and humic acid are jointly exposed to Scenedesmus obliquus and zebrafish (Danio rerio), which can cause low growth inhibition toxicity of algae, conditioned oxidative stress of cells and impaired mitochondrial function, as well as significant effects on oxidative stress and enzymatic antioxidant defense of zebrafish [110]. The temperature of the environment, mode of transport, and type and size of plastic accumulated can potentially affect which chemicals adsorb, to what degree, and how they will encounter humans or aquatic life. Therefore, further studies are also needed to explore how long these chemicals stay adsorbed to the MPs. Previously, results obtained based on animal experiments have shown that MPs can damage the intestinal barrier and reduce intestinal microbial diversity, so the biohazard of combined exposure deserves attention. Equally important, the biofilm formed on the surface of MNPs may promote biological diffusion, invasion, and mutation. The adhesion of different microbial communities to the MNP surface may enhance the flow rates of energy, material, and information in the environment, with long-term and widespread harmful effects [111].

\section{Health impacts of plastic additives of MNPs}

Another critical issue to be considered is the leaching of original plastic additives, such as BPA, phthalates, OFPRs, etc., which have been demonstrated to exhibit endocrine-disrupting effects and other toxicities [112, 113]. The release of plastic additives may take place during the service life of the plastics or after their disposal. An additive's migration potential depends on the polymer's pore diameter, the size of the additive, and its partition coefficient once it reaches the plastic's surface. For example, the additives of a lower molecular weight move much more easily through a polymer with a bigger pore size [114]. More significantly, the environment of the plastics can affect chemical properties of polymers and their additives. For example, rising temperatures can promote movement of additives in polymers [115], and exposure to UV radiation can increase the rate of plastic degradation [116]. In addition, it has also been demonstrated that plastics that are exposed to the salinity of the water in the ocean can desorb estrogenic plasticizers [116]. Plastics in landfills are exposed to leachates of various acidities and chemical properties. Based on those properties, the leachates have various potentials to extract and transport. Different biological populations also have the potential to degrade or transform the released additives [114]. For instance, bacterial populations can colonize, modify, and degrade MPs [117]. With the knowledge that bacteria are present within organisms, it may be important to consider the role they may play in the release of the additives from ingested MPs and the subsequent ramifications this may have on the exposed organism. Taken together, although studies have shown how the chemistry of the environment or the presence of bacteria can impact plastic degradation, there is little knowledge about how these factors come into play for the organisms who ingest MPs. The extent to which plastics can degrade and release additives within the organisms is unknown. More studies are needed to determine the ability for plastic additives to leach from MNPs to the organisms who ingested them, especially considering the extensive knowledge of the endocrine-disrupting effects and other organ toxicities of these plastic additives. 


\section{Feasible control or disposal measures of MNPs}

Since evidence reveals the widespread contamination of MNPs as well as their potentially adverse health impacts on both wildlife animals and humans, researchers also focused on the reduction or elimination of MNPs in the environment, providing possible solutions for protecting both environment and health. One potential option is to look for organisms or other substances that can degrade MNPs. Marine fungus Zalerion maritimum and mixed bacteria have been found to have positive and effective effects on plastic degradation [118, 119]. In addition, a recent study reported that PET polyester plastics could be rapidly and efficiently degraded by special enzymes. ICCG and WCCG, two new variants of leaf-branch compost cutinase (LCC), obtained $90 \%$ depolymerization in $9.3 \mathrm{~h}$ and $10.5 \mathrm{~h}$, respectively. This research develops enzymatic treatment to help solve the plastic treatment problem, which is a good indicator and promotion for achieving sustainable development and circular economy [120]. Furthermore, some traditional plastics have been replaced by biodegradable plastics and degraded by soil composting to reduce environmental pollution. However, these biodegradable plastics also produce MNPs in the composting process, which is worthy of further assessment [121]. For cleaning MNPs in indoor air, the cytotoxic micro polyacrylate styrene and nano-Fe3O4 particles produced by printer toner can be controlled by vacuum-gasification-condensation [122].
Some studies have summarized the pollution situation of MNPs in some developing countries with high population density and fast economic growth, such as India and China, and made useful explorations. For example, the control and elimination of MNPs is advocated to include sewage treatment process to reduce their environmental emissions $[3,123]$.

\section{Conclusion}

In Fig. 2, we summarized the sources, transports, deposition, bioaccumulation, and biomagnification of MNPs, as well as the possible exposure routes of MNPs in both humans and other living organisms. Evidence has suggested harmful health impacts of MNPs on marine and freshwater animals. Thus far, there is no conclusive data regarding the health impact of MNPs on humans. However, it is conceivable that MNPs can be slowly eroded into the intestinal wall into the circulatory system and distribute to various tissues and organs. If accumulated over time, their toxic effects may cause corresponding damages to the human body. The research focused on NPs have just begun. Because of the unique size- and shape-dependent properties of nanoparticles, NPs may exhibit significantly differential impacts from MPs. In Table 2, we summarized the health impact of MNPs, including species, plastic size, type of MNP, discovered health effect, and corresponding references. In summary, we conclude that more studies are necessary, including standardizing sampling methods, establishing qualitative and quantitative measures for

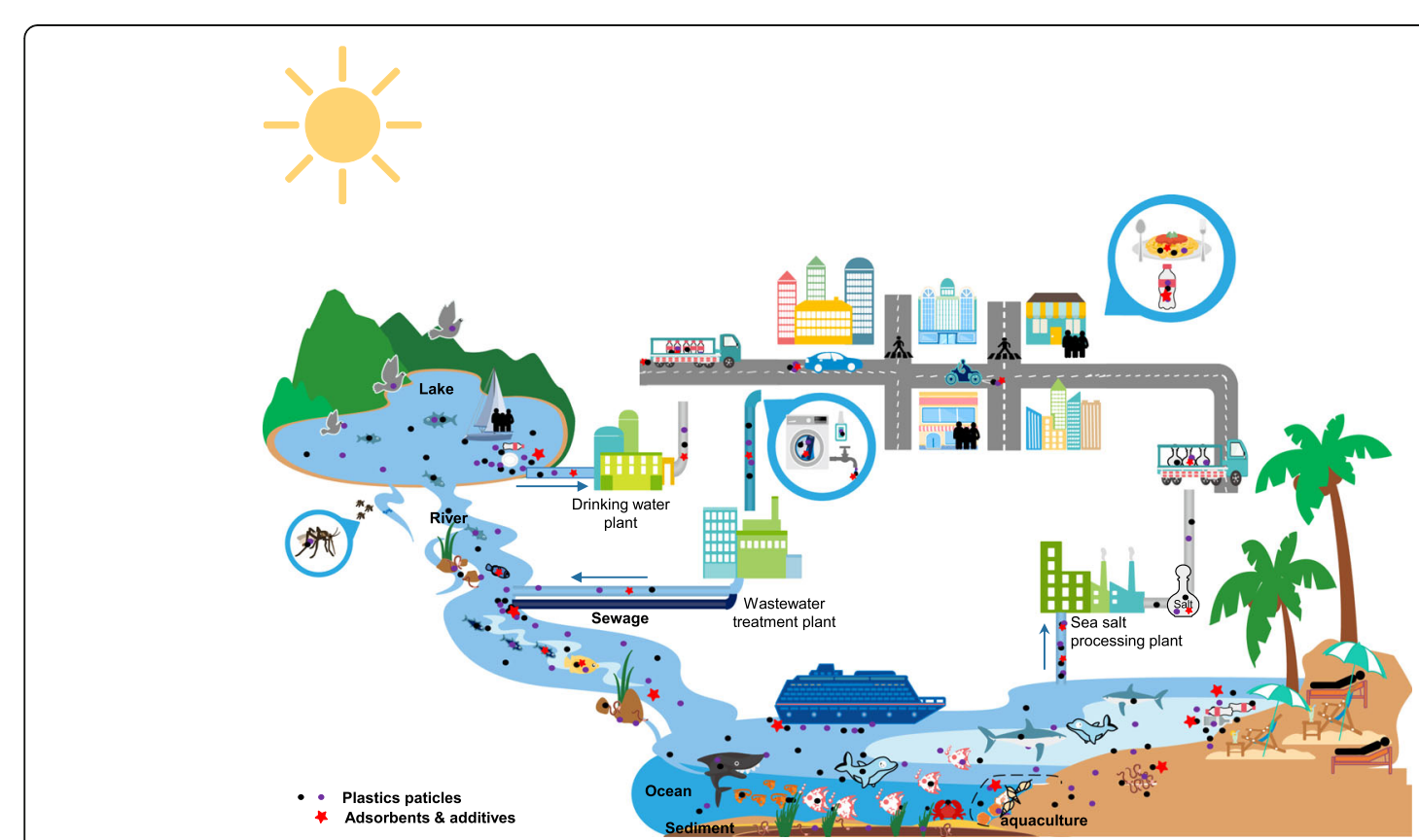

Fig. 2 A summary of sources, transports, and exposure routes of micro- and nanoplastics (MNPs) 
Table 2 A summary of the health impacts of MNPs reviewed in our study

\begin{tabular}{|c|c|c|c|c|}
\hline Species & Size & Type & Effects & Reference \\
\hline \multirow[t]{2}{*}{ Blue mussel } & $4-10 \mu \mathrm{m}$ & MP & Remain in the body & {$[21]$} \\
\hline & $2 \mu \mathrm{m}, 100 \mathrm{~nm}$ & $\mathrm{MP}, \mathrm{NP}$ & $\begin{array}{l}\text { Abnormal development and deformity were found in both MNP } \\
\text { treatment groups, but the growth of mussel larvae was not affected. }\end{array}$ & {$[87]$} \\
\hline \multirow[t]{4}{*}{ Oyster } & $160 \mathrm{~nm}-7.3 \mu \mathrm{m}$ & $M P, N P$ & \multirow{2}{*}{$\begin{array}{l}\text { No measurable adverse effect on the growth, development, or } \\
\text { feeding capacity }\end{array}$} & \multirow[t]{2}{*}{ [88] } \\
\hline & $1 \mu \mathrm{m}, 10 \mu \mathrm{m}$ & MP & & \\
\hline & $2 \mu \mathrm{m}, 6 \mu \mathrm{m}$ & MP & $\begin{array}{l}\text { Significantly reduce the number of follicles and sperm motility in oysters } \\
\text { as well as the production and development of offspring larvae }\end{array}$ & {$[22]$} \\
\hline & $50 \mathrm{~nm}$ & NP & $\begin{array}{l}\text { Significant decrease of oyster fertilization rates and embryo-larval } \\
\text { development, including many deformities, which results in the complete } \\
\text { stagnation of development }\end{array}$ & [89] \\
\hline Clam & $1.2 \mu \mathrm{m}-5 \mathrm{~mm}$ & MNP & $\begin{array}{l}\text { No significant difference for the intake and accumulation of MNPs } \\
\text { between wild and farmed clams }\end{array}$ & [91] \\
\hline \multirow[t]{2}{*}{ Lugworms } & $10-180 \mu \mathrm{m}$ & MP & $\begin{array}{l}\text { Accumulated plastic particles did not have significant effects on the } \\
\text { organisms, nor did they enhance or weaken the bioaccumulation of } \\
\text { other chemicals }\end{array}$ & [93] \\
\hline & $200 \mu \mathrm{m}$ & MP & $\begin{array}{l}\text { Growth and photosynthesis were promoted, and the smaller the } \\
\text { particle size was, the more obvious the effect was. }\end{array}$ & {$[94]$} \\
\hline Crepidula onyx & $2.0-2.4 \mathrm{~mm}$ & MP & Cause abnormal energy consumption & {$[95]$} \\
\hline \multirow[t]{4}{*}{ Daphnia } & $20-250 \mathrm{~mm}$ & MP & Remains in the gut, but there are no acute effects that can be observed & {$[96]$} \\
\hline & $1 \mu \mathrm{m}, 100 \mu \mathrm{m}$ & MP & $\begin{array}{l}\text { The effect of } 1-\mu m \text { plastic particles on immobilization changed in a } \\
\text { time- and dose-dependent manner. However, the } 100-\mu m \text { sized plastic } \\
\text { particles could not be ingested, and there was also no significant harmful } \\
\text { effect for this size of plastic particles. }\end{array}$ & {$[97]$} \\
\hline & $100 \mathrm{~nm}, 2 \mu \mathrm{m}$ & $\mathrm{MP}, \mathrm{NP}$ & $\begin{array}{l}\text { The plastic particles of both sizes are easy to ingest, and the uptake of } \\
2-\mu m \text { particles is } 5 \text { times that of } 100-n m \text { particles. NP resulted in reduced } \\
\text { excretion and ingestion rates, but no adverse effects of MP and NP on } \\
\text { reproduction were observed. }\end{array}$ & {$[98]$} \\
\hline & $63-75 \mu \mathrm{m}$ & MP & $\begin{array}{l}\text { No increase in adult } D \text {. magna mortality after MP exposure, no change in } \\
\text { morphology (length, width, and tailbone length), and no harmful effect } \\
\text { on reproductive parameters }\end{array}$ & {$[96-99,124]$} \\
\hline \multirow[t]{3}{*}{ Zebrafish } & $70 \mathrm{~nm}, 5 \mu \mathrm{m}, 20 \mu \mathrm{m}$ & MP, NP & $\begin{array}{l}5-\mu m \text { MPs can accumulate in the gills, liver, and gut, but } 20-\mu m \text { MPs could } \\
\text { not accumulate in gill tissue. In addition, both } 70-n m \text { and } 5-\mu m \text { MPs can } \\
\text { induce inflammation and lipid accumulation in the liver, with changes in } \\
\text { oxidative stress and lipid energy metabolism }\end{array}$ & {$[23]$} \\
\hline & $\begin{array}{l}\sim 70 \mu \mathrm{m}, 0.1 \mu \mathrm{m} \\
1.0 \mu \mathrm{m}, 5.0 \mu \mathrm{m}\end{array}$ & MP & $\begin{array}{l}\text { Causes intestinal damages, including cracking of villi and splitting of } \\
\text { enterocytes, but does not or rarely cause zebrafish death. The } 1.0-\mu \mathrm{m} \\
\text { particles were highly lethal, had the highest accumulation, the lowest i } \\
\text { ntestinal } \mathrm{Ca}^{2+} \text { level, and the highest expression of glutathione } \\
\text { S-transferase } 4\end{array}$ & [101] \\
\hline & $20-100 \mathrm{~nm}$ & NP & $\begin{array}{l}\text { Penetrate the choroid membranes of developing zebrafish, accumulate in } \\
\text { embryonic tissues, and influence physiology and behavior, leading to } \\
\text { inter- or transgenerational toxicity }\end{array}$ & {$[102,103]$} \\
\hline Japanese medaka & $50-60 \mu \mathrm{m}$ & MF & Increased oviposition and secondary patellar aneurysms & {$[35]$} \\
\hline \multirow[t]{3}{*}{ Mice } & $5 \mu \mathrm{m}, 20 \mu \mathrm{m}$ & MP & $\begin{array}{l}\text { Remain in the liver, kidney, and gut; energy and lipid metabolism } \\
\text { disorders and liver inflammation }\end{array}$ & {$[24]$} \\
\hline & $5 \mu \mathrm{m}, 0.5 \mu \mathrm{m}, 50 \mu \mathrm{m}$ & MP & $\begin{array}{l}\text { Decreased intestinal mucus and significant changes in the richness and } \\
\text { diversity of intestinal biota }\end{array}$ & {$[26,27]$} \\
\hline & $38.92 \mathrm{~nm}$ & NP & $\begin{array}{l}\text { No significant behavioral effects were noted in all neurobehavioral tests. } \\
\text { However, some subtle toxic effects, such as decreased locomotor activity, } \\
\text { were observed, which provides insight for future studies. }\end{array}$ & [104] \\
\hline Human & $50-500 \mu \mathrm{m}$ & MP & $\begin{array}{l}\text { Various MPs have been detected in human feces, suggesting that MPs can } \\
\text { enter the body through the digestive system and be excreted in feces. }\end{array}$ & [125] \\
\hline
\end{tabular}


testing both MPs, NPs, etc. Once these are established, multiple experimental models can be used to study the health impacts of the MNPs themselves, the associated adsorbents and additives on MNPs, as well as the potential biological amplification of the mixtures of these substances.

\section{Abbreviations}

MPs: Microplastics; NPs: Nanoplastics; MNPs: Micro- and nanoplastics; PE: Polyethylene; PP: Polypropylene; PS: Polystyrene; PVC: Polyvinyl chloride; HDPE: High-density polyethylene; LDPE: Low-density polyethylene; MFs: Microplastic fibers; PES: Polyester; Micro-FTIR: Micro-Fourier-transform infrared spectroscopy; SEM: Scanning electron microscope; TEM: Transmission electron microscopy; EDX: Energy dispersive X-ray; STXM: Scanning transmission X-ray microscope; D. magna: Daphnia magna; HOCs: Hydrophobic organic chemicals; EDCs: Endocrine-disrupting chemicals; PCBs: Polychlorinated biphenyls; PFCs: Perfluorinated chemicals; BPA: Bisphenol-A; OPFRs: Organophosphorus flame retardants; NAOP: Natural organic polymers; LCC: Leaf-branch compost cutinase

\section{Acknowledgements}

We thank all authors' contributions to this review paper. As for the limited space, we apologize for not being able to include all previously published studies that contributed to the understanding of the health implications of MNPs.

\section{Authors' contributions}

BJ contributed to the sections "Type and use of plastics", "Occurrence of MNPs in the environment", and "Health impacts of MNPs". AEK contributed to the sections "Health impacts of plastic additives and adsorbents". LL, WM, BC, JW, JRL, SC, and GIS contributed to provide advances of plastic contaminants in the environment and their potential health impacts and the manuscript writing and editing. SX conceived of the project, analyzed and interpreted data, wrote the manuscript, and provided final approval of the manuscript. The author(s) read and approved the final manuscript.

\section{Funding}

This work is supported by the National Science Foundation (NSF 183291) and National Institutes of Health (NIH KO1ES030014) to S. Xiao; National Institutes of Health (NIH P01ES028942) to Gl. Scott, S. Chatterjee, JR. Lead, B. Cai, J. Weinstein, and S. Xiao; and Research Fellowship from China Scholarship Council to B. Jiang.

\section{Availability of data and materials}

All data described, analyzed, or discussed in this review are included in cited publications.

\section{Ethics approval and consent to participate}

Not applicable

\section{Consent for publication}

All authors consent for publishing this work.

\section{Competing interests}

The authors declare no conflict of interest. The scientific results and conclusions, as well as any opinions expressed herein, are those of the author(s) and do not necessarily reflect the views of NOAA or the Department of Commerce. The mention of any commercial product is not meant as an endorsement by the Agency or Department.

\section{Author details}

'Department of Environmental Health Sciences, Arnold School of Public Health, University of South Carolina, Columbia, SC 29208, USA. ${ }^{2}$ NIEHS Center for Oceans and Human Health and Climate Change Interactions (OHHC2I), University of South Carolina, Columbia, SC 29208, USA. ${ }^{3}$ Center for Global Health, School of Public Health, Nanjing Medical University, Nanjing 21009, China. ${ }^{4}$ National Centers for Coastal Ocean Science, National Oceanic and Atmospheric Administration (NOAA), Charleston, SC 29412, USA. ${ }^{5}$ Department of Epidemiology and Biostatistics, Arnold School of Public Health, University of South Carolina, Columbia, SC 29208, USA. ${ }^{6}$ Department of Biology, The Citadel, Military College of South Carolina, Charleston, SC 29409, USA. ${ }^{7}$ Center for Environmental Nanoscience and Risk, Arnold School of Public Health, University of South Carolina, Columbia, SC 29208, USA. ${ }^{8}$ Department of Pharmacology and Toxicology, Ernest Mario School of Pharmacy, Environmental and Occupational Health Sciences Institute, Rutgers University, Piscataway, NJ 08854, USA.

Received: 5 May 2020 Accepted: 5 July 2020

Published online: 14 July 2020

\section{References}

1. Gigault J, ter Halle A, Baudrimont M, Pascal PY, Gauffre F, Phi TL, et al. Current opinion: What is a nanoplastic? Environ Pollut. 2018;235:1030-4 https://doi.org/10.1016/j.envpol.2018.01.024.

2. Wang MH, He Y, Sen B. Research and management of plastic pollution in coastal environments of China. Environ Pollut. 2019;248:898-905. https://doi. org/10.1016/j.envpol.2019.02.098.

3. Wang T, Li B, Zou X, Wang Y, Li Y, Xu Y, et al. Emission of primary microplastics in mainland China: Invisible but not negligible. Water Res. 2019;162:214-24. https://doi.org/10.1016/j.watres.2019.06.042.

4. Geyer R, Jambeck JR, Law KL. Production, use, and fate of all plastics ever made. Sci Adv. 2017;3. doi:ARTN e1700782. https://doi.org/10.1126/sciadv. 1700782.

5. Guglielmi G: In the next 30 years, we'll make four times more plastic waste than we ever have. https://www.sciencemag.org/news/2017/07/next-30years-we-II-make-four-times-more-plastic-waste-we-ever-have (2017). Accessed Jul. 19, 2017

6. Rhodes CJ. Plastic pollution and potential solutions. Sci Progress-Uk. 2018; 101:207-60. https://doi.org/10.3184/003685018X15294876706211.

7. Liu J, Lezama N, Gasper J, Kawata J, Morley S, Helmer D, et al. Burn Pit Emissions Exposure and Respiratory and Cardiovascular Conditions Among Airborne Hazards and Open Burn Pit Registry Participants. J Occup Environ Med. 2016;58:e249-55. https://doi.org/10.1097/JOM.0000000000000776.

8. Kubowicz S, Booth AM. Biodegradability of Plastics: Challenges and Misconceptions. Environ Sci Technol. 2017;51:12058-60. https://doi.org/10. 1021/acs.est.7b04051.

9. Avio CG, Gorbi S, Regoli F. Plastics and microplastics in the oceans: From emerging pollutants to emerged threat. Mar Environ Res. 2017;128:2-11. https://doi.org/10.1016/.marenvres.2016.05.012.

10. Waring RH, Harris RM, Mitchell SC. Plastic contamination of the food chain: A threat to human health? Maturitas. 2018;115:64-8. https://doi.org/10.1016/ j.maturitas.2018.06.010

11. Sharma S, Chatterjee S. Microplastic pollution, a threat to marine ecosystem and human health: a short review. Environ Sci Pollut Res Int. 2017;24:2153047. https://doi.org/10.1007/s11356-017-9910-8.

12. Lehner R, Weder C, Petri-Fink A, Rothen-Rutishauser B. Emergence of Nanoplastic in the Environment and Possible Impact on Human Health. Environ Sci Technol. 2019;53:1748-65. https://doi.org/10.1021/acs.est. $8 \mathrm{~b} 05512$.

13. Adawi HI, Newbold MA, Reed JM, Vance ME, Feitshans IL, Bickford LR, et al. Nano-enabled personal care products: Current developments in consumer safety. Nanoimpact. 2018;11:170-9. https://doi.org/10.1016/j.impact.2018.08. 002.

14. Hernandez $L M, X u$ EG, Larsson HCE, Tahara R, Maisuria VB, Tufenkji N. Plastic Teabags Release Billions of Microparticles and Nanoparticles into Tea. Environ Sci Technol. 2019;53:12300-10. https://doi.org/10.1021/acs.est. 9b02540.

15. Chae $Y$, An YJ. Effects of micro- and nanoplastics on aquatic ecosystems: Current research trends and perspectives. Mar Pollut Bull. 2017;124:624-32 https://doi.org/10.1016/j.marpolbul.2017.01.070.

16. Peeken I, Primpke S, Beyer B, Gutermann J, Katlein C, Krumpen T, et al. Arctic sea ice is an important temporal sink and means of transport for microplastic. Nat Commun. 2018;9:1505. https://doi.org/10.1038/s41467-01803825-5.

17. Auta HS, Emenike CU, Fauziah SH. Distribution and importance of microplastics in the marine environment: A review of the sources, fate, effects, and potential solutions. Environ Int. 2017;102:165-76. https://doi.org/ 10.1016/j.envint.2017.02.013.

18. Lambert $\mathrm{S}$, Wagner M. Characterisation of nanoplastics during the degradation of polystyrene. Chemosphere. 2016;145:265-8. https://doi.org/ 10.1016/j.chemosphere.2015.11.078. 
19. Alimi OS, Farner Budarz J, Hernandez LM, Tufenkji N. Microplastics and Nanoplastics in Aquatic Environments: Aggregation, Deposition, and Enhanced Contaminant Transport. Environ Sci Technol. 2018;52:1704-24. https://doi.org/10.1021/acs.est.7b05559.

20. Cozar A, Echevarria F, Gonzalez-Gordillo Jl, Irigoien X, Ubeda B, HernandezLeon S, et al. Plastic debris in the open ocean. Proc Natl Acad Sci U S A. 2014;111:10239-44. https://doi.org/10.1073/pnas.1314705111.

21. Bouwmeester H, Hollman PC, Peters RJ. Potential Health Impact of Environmentally Released Micro- and Nanoplastics in the Human Food Production Chain: Experiences from Nanotoxicology. Environ Sci Technol. 2015;49:8932-47. https://doi.org/10.1021/acs.est.5b01090.

22. Sussarellu $R$, Suquet $M$, Thomas $Y$, Lambert C, Fabioux C, Pernet MEJ, et al. Oyster reproduction is affected by exposure to polystyrene microplastics. Proc Natl Acad Sci U S A. 2016;113:2430-5. https://doi.org/10.1073/pnas. 1519019113.

23. Lu Y, Zhang Y, Deng Y, Jiang W, Zhao Y, Geng J, et al. Uptake and Accumulation of Polystyrene Microplastics in Zebrafish (Danio rerio) and Toxic Effects in Liver. Environ Sci Technol. 2016;50:4054-60. https://doi.org/ 10.1021/acs.est.6b00183.

24. Deng $Y$, Zhang $Y$, Lemos $B$, Ren $H$. Tissue accumulation of microplastics in mice and biomarker responses suggest widespread health risks of exposure. Sci Rep. 2017;7:46687. https://doi.org/10.1038/srep46687.

25. Yang YF, Chen CY, Lu TH, Liao CM. Toxicity-based toxicokinetic/ toxicodynamic assessment for bioaccumulation of polystyrene microplastics in mice. J Hazard Mater. 2019;366:703-13. https://doi.org/10.1016/j.jhazmat. 2018.12.048.

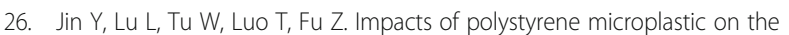
gut barrier, microbiota and metabolism of mice. Sci Total Environ. 2019;649: 308-17. https://doi.org/10.1016/j.scitotenv.2018.08.353.

27. Lu L, Wan Z, Luo T, Fu Z, Jin Y. Polystyrene microplastics induce gut microbiota dysbiosis and hepatic lipid metabolism disorder in mice. Sci Total Environ. 2018;631-632:449-58. doi:https://doi.org/10.1016/j.scitotenv. 2018.03.051

28. Prata JC, da Costa JP, Lopes I, Duarte AC, Rocha-Santos T. Environmental exposure to microplastics: An overview on possible human health effects. Sci Total Environ. 2020;702:134455. https://doi.org/10.1016/j.scitotenv.2019. 134455

29. Huerta Lwanga E, Mendoza Vega J, Ku Quej V, Chi JLA, Sanchez Del Cid L, Chi $C$, et al. Field evidence for transfer of plastic debris along a terrestrial food chain. Sci Rep. 2017;7:14071. https://doi.org/10.1038/s41598-017-145882

30. Rudyak W, Efimova EA, Guseva DV, Chertovich AV. Thermoset Polymer Matrix Structure and Properties: Coarse-Grained Simulations. Polymers (Basel). 2018;11. doi:https://doi.org/10.3390/polym11010036.

31. Mattsson K, Hansson LA, Cedervall T. Nano-plastics in the aquatic environment. Environ Sci Process Impacts. 2015;17:1712-21. https://doi.org/ 10.1039/c5em00227c.

32. Battulga B, Kawahigashi M, Oyuntsetseg B. Distribution and composition of plastic debris along the river shore in the Selenga River basin in Mongolia. Environ Sci Pollut Res Int. 2019;26:14059-72. https://doi.org/10.1007/s11356019-04632-1.

33. Xu Y, He Q, Liu C, Huangfu X. Are Micro- or Nanoplastics Leached from Drinking Water Distribution Systems? Environ Sci Technol. 2019;53:9339-40. https://doi.org/10.1021/acs.est.9b03673.

34. Raddadi N, Fava F. Biodegradation of oil-based plastics in the environment: Existing knowledge and needs of research and innovation. Sci Total Environ. 2019;679:148-58. https://doi.org/10.1016/j.scitotenv.2019.04.419.

35. Hu L, Chernick M, Lewis AM, Ferguson PL, Hinton DE. Chronic microfiber exposure in adult Japanese medaka (Oryzias latipes). PLoS One. 2020:15: e0229962. https://doi.org/10.1371/journal.pone.0229962.

36. Cole M. A novel method for preparing microplastic fibers. Sci Rep. 2016;6: 34519. https://doi.org/10.1038/srep34519.

37. Liu J, Yang Y, Ding J, Zhu B, Gao W. Microfibers: a preliminary discussion on their definition and sources. Environ Sci Pollut Res Int. 2019:26:29497-501. https://doi.org/10.1007/s11356-019-06265-w

38. Suresh SS, Mohanty S, Nayak SK. Composition analysis and characterization of waste polyvinyl chloride (PVC) recovered from data cables. Waste Manag. 2017;60:100-11. https://doi.org/10.1016/j.wasman.2016.08.033.

39. Van Cauwenberghe $L$, Claessens M, Vandegehuchte MB, Janssen CR. Microplastics are taken up by mussels (Mytilus edulis) and lugworms
(Arenicola marina) living in natural habitats. Environ Pollut. 2015;199:10-7. https://doi.org/10.1016/j.envpol.2015.01.008.

40. Deng YF, Zhang Y, Qiao RX, Bonila MM, Yang XL, Ren HQ, et al. Evidence that microplastics aggravate the toxicity of organophosphorus flame retardants in mice (Mus musculus). J Hazard Mater. 2018;357:348-54. https:// doi.org/10.1016/j.jhazmat.2018.06.017.

41. Wu P, Cai Z, Jin H, Tang Y. Adsorption mechanisms of five bisphenol analogues on PVC microplastics. Sci Total Environ. 2019;650:671-8. https:// doi.org/10.1016/j.scitotenv.2018.09.049.

42. Amelineau F, Bonnet D, Heitz O, Mortreux V, Harding AMA, Karnovsky N, et al. Microplastic pollution in the Greenland Sea: Background levels and selective contamination of planktivorous diving seabirds. Environ Pollut. 2016;219:1131-9. https://doi.org/10.1016/j.envpol.2016.09.017.

43. Anderson AG, Grose J, Pahl S, Thompson RC, Wyles KJ. Microplastics in personal care products: Exploring perceptions of environmentalists, beauticians and students. Mar Pollut Bull. 2016;113:454-60. https://doi.org/ 10.1016/j.marpolbul.2016.10.048.

44. Godoy V, Martin-Lara MA, Calero M, Blazquez G. Physical-chemical characterization of microplastics present in some exfoliating products from Spain. Mar Pollut Bull. 2019;139:91-9. https://doi.org/10.1016/j.marpolbul. 2018.12.026.

45. Guerranti C, Martellini T, Perra G, Scopetani C, Cincinelli A. Microplastics in cosmetics: Environmental issues and needs for global bans. Environ Toxicol Pharmacol. 2019;68:75-9. https://doi.org/10.1016/j.etap.2019.03.007.

46. Praveena SM, Shaifuddin SNM, Akizuki S. Exploration of microplastics from personal care and cosmetic products and its estimated emissions to marine environment: An evidence from Malaysia. Mar Pollut Bull. 2018;136:135-40. https://doi.org/10.1016/.marpolbul.2018.09.012.

47. Cheung PK, Fok L. Evidence of microbeads from personal care product contaminating the sea. Mar Pollut Bull. 2016;109:582-5. https://doi.org/10. 1016/j.marpolbul.2016.05.046.

48. Yurtsever M. Tiny, shiny, and colorful microplastics: Are regular glitters a significant source of microplastics? Mar Pollut Bull. 2019;146:678-82. https:// doi.org/10.1016/j.marpolbul.2019.07.009.

49. Au SY, Lee CM, Weinstein JE, van den Hurk P, Klaine SJ. Trophic transfer of microplastics in aquatic ecosystems: Identifying critical research needs. Integr Environ Assess Manag. 2017;13:505-9. https://doi.org/10.1002/ieam. 1907.

50. Hebner TS, Maurer-Jones MA. Characterizing microplastic size and morphology of photodegraded polymers placed in simulated moving water conditions. Environ Sci Process Impacts. 2020;22:398-407. https://doi.org/10. 1039/c9em00475k.

51. Weinstein JE, Crocker BK, Gray AD. From macroplastic to microplastic: Degradation of high-density polyethylene, polypropylene, and polystyrene in a salt marsh habitat. Environ Toxicol Chem. 2016;35:1632-40. https://doi. org/10.1002/etc.3432.

52. Wright SL, Kelly FJ. Plastic and Human Health: A Micro Issue? Environ Sci Technol. 2017;51:6634-47. https://doi.org/10.1021/acs.est.7b00423.

53. Sommer F, Dietze V, Baum A, Sauer J, Gilge S, Maschowski C, et al. Tire Abrasion as a Major Source of Microplastics in the Environment. Aerosol Air Qual Res. 2018:18:2014-28. https://doi.org/10.4209/aaqr.2018.03.0099.

54. Kole PJ, Lohr AJ, Van Belleghem F, Ragas AMJ. Wear and Tear of Tyres: A Stealthy Source of Microplastics in the Environment. Int J Environ Res Public Health. 2017;14. https://doi.org/10.3390/ijerph14101265.

55. Guzzetti E, Sureda A, Tejada S, Faggio C. Microplastic in marine organism: Environmental and toxicological effects. Environ Toxicol Pharmacol. 2018;64: 164-71. https://doi.org/10.1016/j.etap.2018.10.009.

56. Al-Jaibachi R, Cuthbert RN, Callaghan A. Up and away: ontogenic transference as a pathway for aerial dispersal of microplastics. Biol Letters. 2018;14. doi:Artn 20180479. https://doi.org/10.1098/Rsbl.2018.0479.

57. Qi Y, Yang X, Pelaez AM, Huerta Lwanga E, Beriot N, Gertsen H, et al. Macroand micro- plastics in soil-plant system: Effects of plastic mulch film residues on wheat (Triticum aestivum) growth. Sci Total Environ. 2018;645:1048-56. https://doi.org/10.1016/j.scitotenv.2018.07.229.

58. Ng EL, Huerta Lwanga E, Eldridge SM, Johnston P, Hu HW, Geissen V, et al. An overview of microplastic and nanoplastic pollution in agroecosystems. Sci Total Environ. 2018;627:1377-88. https://doi.org/10.1016/j.scitotenv.2018. 01.341.

59. Rillig MC, Ziersch L, Hempel S. Microplastic transport in soil by earthworms. Sci Rep. 2017:7:1362. https://doi.org/10.1038/s41598-017-01594-7. 
60. Kim SW, An YJ. Soil microplastics inhibit the movement of springtail species. Environ Int. 2019;126:699-706. https://doi.org/10.1016/j.envint.2019.02.067.

61. Anderson PJ, Warrack S, Langen V, Challis JK, Hanson ML, Rennie MD. Microplastic contamination in Lake Winnipeg, Canada. Environ Pollut. 2017; 225:223-31. https://doi.org/10.1016/j.envpol.2017.02.072.

62. Wang W, Ndungu AW, Li Z, Wang J. Microplastics pollution in inland freshwaters of China: A case study in urban surface waters of Wuhan, China. Sci Total Environ. 2017;575:1369-74. https://doi.org/10.1016/j.scitotenv.2016. 09.213.

63. Schymanski D, Goldbeck C, Humpf HU, Furst P. Analysis of microplastics in water by micro-Raman spectroscopy: Release of plastic particles from different packaging into mineral water. Water Res. 2018;129:154-62. https:// doi.org/10.1016/j.watres.2017.11.011.

64. Pivokonsky M, Cermakova L, Novotna K, Peer P, Cajthaml T, Janda V. Occurrence of microplastics in raw and treated drinking water. Sci Total Environ. 2018;643:1644-51. https://doi.org/10.1016/j.scitotenv.2018.08.102.

65. Mintenig SM, Loder MGJ, Primpke S, Gerdts G. Low numbers of microplastics detected in drinking water from ground water sources. Sci Total Environ. 2019;648:631-5. https://doi.org/10.1016/j.scitotenv.2018.08.178.

66. Peng G, Zhu B, Yang D, Su L, Shi H, Li D. Microplastics in sediments of the Changjiang Estuary, China. Environ Pollut. 2017;225:283-90. https://doi.org/ 10.1016/j.envpol.2016.12.064.

67. Peng G, Xu P, Zhu B, Bai M, Li D. Microplastics in freshwater river sediments in Shanghai, China: A case study of risk assessment in mega-cities. Environ Pollut. 2018;234:448-56. https://doi.org/10.1016/j.envpol.2017.11.034.

68. Karthik R, Robin RS, Purvaja R, Ganguly D, Anandavelu I, Raghuraman R, et al. Microplastics along the beaches of southeast coast of India. Sci Total Environ. 2018;645:1388-99. https://doi.org/10.1016/j.scitotenv.2018.07.242.

69. Gray AD, Wertz H, Leads RR, Weinstein JE. Microplastic in two South Carolina Estuaries: Occurrence, distribution, and composition. Mar Pollut Bull. 2018;128:223-33. https://doi.org/10.1016/j.marpolbul.2018.01.030.

70. Iniguez ME, Conesa JA, Fullana A. Microplastics in Spanish Table Salt. Sci Rep. 2017;7:8620. https://doi.org/10.1038/s41598-017-09128-X.

71. Yang D, Shi H, Li L, Li J, Jabeen K, Kolandhasamy P. Microplastic Pollution in Table Salts from China. Environ Sci Technol. 2015;49:13622-7. https://doi. org/10.1021/acs.est.5b03163.

72. Peeken I, Primpke S, Beyer B, Gutermann J, Katlein C, Krumpen T, et al. Arctic sea ice is an important temporal sink and means of transport for microplastic. Nat Commun. 2018;9. doi:Artn 1505. https://doi.org/10.1038/ S41467-018-03825-5.

73. Yu XB, Ladewig S, Bao SW, Toline CA, Whitmire S, Chow AT. Occurrence and distribution of microplastics at selected coastal sites along the southeastern United States. Sci Total Environ. 2018;613:298-305. https://doi.org/10.1016/j. scitotenv.2017.09.100.

74. Bigalke M, Filella M, Fischer D, Muntwyler A, Scheurer M, Watts B. Microand Nanoplastic Analysis in Soils. Chimia. 2018;72:901. https://doi.org/10. 2533/chimia.2018.901.

75. Dehghani S, Moore F, Akhbarizadeh R. Microplastic pollution in deposited urban dust, Tehran metropolis, Iran. Environ Sci Pollut Res Int. 2017;24: 20360-71. https://doi.org/10.1007/s11356-017-9674-1.

76. Peiponen KE, Raty J, Ishaq U, Pelisset S, Ali R. Outlook on optical identification of micro- and nanoplastics in aquatic environments Chemosphere. 2019;214:424-9. https://doi.org/10.1016/j.chemosphere.2018. 09.111.

77. Wang ZM, Wagner J, Ghosal S, Bedi G, Wall S. SEM/EDS and optical microscopy analyses of microplastics in ocean trawl and fish guts. Sci Total Environ. 2017;603-604:616-26. doi:https://doi.org/10.1016/j.scitotenv.2017.06. 047.

78. Toussaint B, Raffael B, Angers-Loustau A, Gilliland D, Kestens V, Petrillo M, et al. Review of micro- and nanoplastic contamination in the food chain. Food Addit Contam Part A Chem Anal Control Expo Risk Assess. 2019;36: 639-73. https://doi.org/10.1080/19440049.2019.1583381

79. Franzellitti S, Canesi L, Auguste M, Wathsala R, Fabbri E. Microplastic exposure and effects in aquatic organisms: A physiological perspective. Environ Toxicol Pharmacol. 2019;68:37-51. https://doi.org/10.1016/j.etap. 2019.03.009.

80. von Moos N, Burkhardt-Holm P, Kohler A. Uptake and effects of microplastics on cells and tissue of the blue mussel Mytilus edulis $\mathrm{L}$. after an experimental exposure. Environ Sci Technol. 2012;46:11327-35. https://doi. org/10.1021/es302332w.
81. Capolupo M, Franzellitti S, Valbonesi P, Lanzas CS, Fabbri E. Uptake and transcriptional effects of polystyrene microplastics in larval stages of the Mediterranean mussel Mytilus galloprovincialis. Environ Pollut. 2018;241: 1038-47. https://doi.org/10.1016/j.envpol.2018.06.035.

82. Fernandez B, Albentosa M. Insights into the uptake, elimination and accumulation of microplastics in mussel. Environ Pollut. 2019;249:321-9. https://doi.org/10.1016/j.envpol.2019.03.037.

83. Magara G, Elia AC, Syberg K, Khan FR. Single contaminant and combined exposures of polyethylene microplastics and fluoranthene: accumulation and oxidative stress response in the blue mussel, Mytilus edulis. Journal of toxicology and environmental health Part A. 2018;81:761-73. https://doi.org/ 10.1080/15287394.2018.1488639.

84. Van Cauwenberghe $L$, Janssen CR. Microplastics in bivalves cultured for human consumption. Environ Pollut. 2014;193:65-70. https://doi.org/10. 1016/j.envpol.2014.06.010.

85. Rist S, Steensgaard IM, Guven O, Nielsen TG, Jensen LH, Moller LF, et al. The fate of microplastics during uptake and depuration phases in a blue mussel exposure system. Environ Toxicol Chem. 2019;38:99-105. https://doi.org/10. 1002/etc.4285.

86. Riisgard HU. Efficiency of Particle Retention and Filtration-Rate in 6 Species of Northeast American Bivalves. Mar Ecol Prog Ser. 1988;45:217-23. https:// doi.org/10.3354/Meps045217.

87. Rist S, Baun A, Almeda R, Hartmann NB. Ingestion and effects of micro- and nanoplastics in blue mussel (Mytilus edulis) larvae. Mar Pollut Bull. 2019;140: 423-30. https://doi.org/10.1016/j.marpolbul.2019.01.069.

88. Cole M, Galloway TS. Ingestion of Nanoplastics and Microplastics by Pacific Oyster Larvae. Environ Sci Technol. 2015;49:14625-32. https://doi.org/10. 1021/acs.est.5b04099.

89. Tallec K, Huvet A, Di Poi C, Gonzalez-Fernandez C, Lambert C, Petton B, et al. Nanoplastics impaired oyster free living stages, gametes and embryos. Environ Pollut. 2018;242:1226-35. https://doi.org/10.1016/j.envpol.2018.08. 020.

90. Li J, Qu X, Su L, Zhang W, Yang D, Kolandhasamy P, et al. Microplastics in mussels along the coastal waters of China. Environ Pollut. 2016;214:177-84. https://doi.org/10.1016/j.envpol.2016.04.012.

91. Davidson K, Dudas SE. Microplastic Ingestion by Wild and Cultured Manila Clams (Venerupis philippinarum) from Baynes Sound, British Columbia. Arch Environ Contam Toxicol. 2016;71:147-56. https://doi.org/10.1007/s00244016-0286-4

92. Su L, Cai HW, Kolandhasamy P, Wu CX, Rochman CM, Shi HH. Using the Asian clam as an indicator of microplastic pollution in freshwater ecosystems. Environ Pollut. 2018;234:347-55. https://doi.org/10.1016/j. envpol.2017.11.075.

93. Besseling E, Foekema EM, van den Heuvel-Greve MJ, Koelmans AA. The Effect of Microplastic on the Uptake of Chemicals by the Lugworm Arenicola marina (L.) under Environmentally Relevant Exposure Conditions. Environ Sci Technol. 2017;51:8795-804. https://doi.org/10.1021/acs.est. 7 b02286.

94. Chae Y, Kim D, An YJ. Effects of micro-sized polyethylene spheres on the marine microalga Dunaliella salina: Focusing on the algal cell to plastic particle size ratio. Aquat Toxicol. 2019;216:105296. https://doi.org/10.1016/j. aquatox.2019.105296.

95. Lo HKA, Chan KYK. Negative effects of microplastic exposure on growth and development of Crepidula onyx. Environ Pollut. 2018;233:588-95. https://doi. org/10.1016/j.envpol.2017.10.095.

96. Kokalj AJ, Kunej U, Skalar T. Screening study of four environmentally relevant microplastic pollutants: Uptake and effects on Daphnia magna and Artemia franciscana. Chemosphere. 2018;208:522-9. https://doi.org/10.1016/ j.chemosphere.2018.05.172.

97. Rehse S, Kloas W, Zarfl C. Short-term exposure with high concentrations of pristine microplastic particles leads to immobilisation of Daphnia magna. Chemosphere. 2016;153:91-9. https://doi.org/10.1016/j.chemosphere.2016. 02.133 .

98. Rist S, Baun A, Hartmann NB. Ingestion of micro- and nanoplastics in Daphnia magna - Quantification of body burdens and assessment of feeding rates and reproduction. Environ Pollut. 2017;228:398-407. https:// doi.org/10.1016/j.envpol.2017.05.048.

99. Canniff PM, Hoang TC. Microplastic ingestion by Daphnia magna and its enhancement on algal growth. Sci Total Environ. 2018;633:500-7. https:// doi.org/10.1016/j.scitotenv.2018.03.176. 
100. Imhof HK, Rusek J, Thiel M, Wolinska J, Laforsch C. Do microplastic particles affect Daphnia magna at the morphological, life history and molecular level? Plos One. 2017;12. doi:ARTN e0187590. https://doi.org/10.1371/journal. pone.0187590

101. Lei L, Wu S, Lu S, Liu M, Song Y, Fu Z, et al. Microplastic particles cause intestinal damage and other adverse effects in zebrafish Danio rerio and nematode Caenorhabditis elegans. Sci Total Environ. 2018;619-620:1-8. doi: 10.1016/j.scitotenv.2017.11.103.

102. Pitt JA, Kozal JS, Jayasundara N, Massarsky A, Trevisan R, Geitner N, et al. Uptake, tissue distribution, and toxicity of polystyrene nanoparticles in developing zebrafish (Danio rerio). Aquat Toxicol. 2018;194:185-94. https:// doi.org/10.1016/j.aquatox.2017.11.017.

103. Lee WS, Cho HJ, Kim E, Huh YH, Kim HJ, Kim B, et al. Bioaccumulation of polystyrene nanoplastics and their effect on the toxicity of Au ions in zebrafish embryos. Nanoscale. 2019;11:3173-85. https://doi.org/10.1039/ c8nr09321k

104. Rafiee M, Dargahi L, Eslami A, Beirami E, Jahangiri-Rad M, Sabour S, et al. Neurobehavioral assessment of rats exposed to pristine polystyrene nanoplastics upon oral exposure. Chemosphere. 2018;193:745-53. https:// doi.org/10.1016/j.chemosphere.2017.11.076.

105. Karwacka A, Zamkowska D, Radwan M, Jurewicz J. Exposure to modern, widespread environmental endocrine disrupting chemicals and their effect on the reproductive potential of women: an overview of current epidemiological evidence. Hum Fertil. 2019;22:2-25. https://doi.org/10.1080/ 14647273.2017.1358828.

106. Lee H, Shim WJ, Kwon JH. Sorption capacity of plastic debris for hydrophobic organic chemicals. The Science of the total environment. 2014; 470-471:1545-52. doi:https://doi.org/10.1016/j.scitotenv.2013.08.023.

107. Munier B, Bendell LI. Macro and micro plastics sorb and desorb metals and act as a point source of trace metals to coastal ecosystems. Plos One. 2018; 13. doi:ARTN e0191759. https://doi.org/10.1371/journal.pone.0191759.

108. Rochman CM, Hentschel BT, Teh SJ. Long-Term Sorption of Metals Is Similar among Plastic Types: Implications for Plastic Debris in Aquatic Environments. Plos One. 2014;9. doi:ARTN e85433. https://doi.org/10.1371/ journal.pone.0085433.

109. Barboza LGA, Vieira LR, Branco V, Fiqueiredo N, Carvalho F, Carvalho C, et al. Microplastics cause neurotoxicity, oxidative damage and energy-related changes and interact with the bioaccumulation of mercury in the European seabass, Dicentrarchus labrax (Linnaeus, 1758). Aquat Toxicol. 2018;195:4957. https://doi.org/10.1016/j.aquatox.2017.12.008.

110. Wang Y, Liu M, Johnson SB, Yuan G, Arriba AK, Zubizarreta ME, et al. Doxorubicin obliterates mouse ovarian reserve through both primordial follicle atresia and overactivation. Toxicol Appl Pharmacol. 2019;381:114714. https://doi.org/10.1016/j.taap.2019.114714.

111. Shen $M$, Zhu Y, Zhang Y, Zeng G, Wen X, Yi H, et al. Micro(nano)plastics: Unignorable vectors for organisms. Mar Pollut Bull. 2019;139:328-31. https:// doi.org/10.1016/j.marpolbul.2019.01.004

112. Gore AC, Chappell VA, Fenton SE, Flaws JA, Nadal A, Prins GS, et al. EDC-2: The Endocrine Society's Second Scientific Statement on EndocrineDisrupting Chemicals. Endocr Rev. 2015;36:E1-E150. https://doi.org/10.1210/ er.2015-1010.

113. Diamanti-Kandarakis E, Bourguignon JP, Giudice LC, Hauser R, Prins GS, Soto AM, et al. Endocrine-disrupting chemicals: an Endocrine Society scientific statement. Endocr Rev. 2009;30:293-342. https://doi.org/10.1210/er.20090002.

114. Teuten EL, Saquing JM, Knappe DR, Barlaz MA, Jonsson S, Bjorn A, et al. Transport and release of chemicals from plastics to the environment and to wildlife. Philos Trans R Soc Lond Ser B Biol Sci. 2009;364:2027-45. https:// doi.org/10.1098/rstb.2008.0284

115. Bjorn A, Horsing M, Karlsson A, Mersiowsky I, Ejlertsson J. Impacts of temperature on the leaching of organotin compounds from poly(vinyl chloride) plastics - A study conducted under simulated landfill conditions. J Vinyl Addit Techn. 2007;13:176-88. https://doi.org/10.1002/vnl.20131.

116. Coffin S, Dudley S, Taylor A, Wolf D, Wang J, Lee I, et al. Comparisons of analytical chemistry and biological activities of extracts from North Pacific gyre plastics with UV-treated and untreated plastics using in vitro and in vivo models. Environ Int. 2018;121:942-54. https://doi.org/10.1016/j.envint. 2018.10.012.

117. Auta HS, Emenike CU, Jayanthi B, Fauziah SH. Growth kinetics and biodeterioration of polypropylene microplastics by Bacillus sp. and
Rhodococcus sp. isolated from mangrove sediment. Mar Pollut Bull. 2018; 127:15-21. https://doi.org/10.1016/j.marpolbul.2017.11.036.

118. Paco A, Duarte K, da Costa JP, Santos PSM, Pereira R, Pereira ME, et al. Biodegradation of polyethylene microplastics by the marine fungus Zalerion maritimum. Sci Total Environ. 2017;586:10-5. https://doi.org/10.1016/j. scitotenv.2017.02.017.

119. Park SY, Kim CG. Biodegradation of micro-polyethylene particles by bacterial colonization of a mixed microbial consortium isolated from a landfill site. Chemosphere. 2019;222:527-33. https://doi.org/10.1016/j.chemosphere.2019. 01.159.

120. Tournier V, Topham CM, Gilles A, David B, Folgoas C, Moya-Leclair E, et al. An engineered PET depolymerase to break down and recycle plastic bottles. Nature. 2020;580:216-9. https://doi.org/10.1038/s41586-020-2149-4.

121. Sintim HY, Bary Al, Hayes DG, English ME, Schaeffer SM, Miles CA, et al. Release of micro- and nanoparticles from biodegradable plastic during in situ composting. Sci Total Environ. 2019;675:686-93. https://doi.org/10.1016/ j.scitotenv.2019.04.179.

122. Ruan J, Qin B, Huang J. Controlling measures of micro-plastic and nano pollutants: A short review of disposing waste toners. Environ Int. 2018;118: 92-6. https://doi.org/10.1016/j.envint.2018.05.038.

123. Lee $H$, Kim $Y$. Treatment characteristics of microplastics at biological sewage treatment facilities in Korea. Mar Pollut Bull. 2018;137:1-8. https://doi.org/10. 1016/j.marpolbul.2018.09.050

124. Imhof HK, Rusek J, Thiel M, Wolinska J, Laforsch C. Do microplastic particles affect Daphnia magna at the morphological, life history and molecular level? PLoS One. 2017;12:e0187590. https://doi.org/10.1371/journal.pone. 0187590.

125. Schwabl P, Koppel S, Konigshofer P, Bucsics T, Trauner M, Reiberger T, et al. Detection of Various Microplastics in Human Stool A Prospective Case Series. Ann Intern Med. 2019;171:453. https://doi.org/10.7326/M19-0618.

\section{Publisher's Note}

Springer Nature remains neutral with regard to jurisdictional claims in published maps and institutional affiliations.

Ready to submit your research? Choose BMC and benefit from:

- fast, convenient online submission

- thorough peer review by experienced researchers in your field

- rapid publication on acceptance

- support for research data, including large and complex data types

- gold Open Access which fosters wider collaboration and increased citations

- maximum visibility for your research: over $100 \mathrm{M}$ website views per year

At BMC, research is always in progress.

Learn more biomedcentral.com/submissions 